\title{
Analysis of Knowledge and Adoption of Rice Cultivators Trained by KVKs in Central Plain Zone of Uttar Pradesh, India
}

\author{
Sunil Kumar ${ }^{1}$, H. C. Singh², Arun Kumar Rajbhar ${ }^{3 *}$, \\ Ramratan Singh ${ }^{1}$ and Ramvinay Pal $^{1}$
}

\author{
${ }^{1}$ C.S. Azad University of Agriculture \& Technology, Kanpur (U P) India \\ ${ }^{2}$ Faculty of Agril. Engg. and Technology (CSAUA\&T, Kanpur), Campus -Etawah, U.P., India \\ 3- School of Agriculture, Lovely Professional University, Jalandhar, Punjab, India
}

*Corresponding author

\section{A B S T R A C T}

\begin{tabular}{|l|}
\hline Ke y w o r d s \\
knowledge, \\
adoption, rice \\
cultivator, KVKs
\end{tabular}

Rice is one of the most important food crops of India. Major share of rice is cultivated during Kharif season. The KVK is innovative institution for disseminating new agricultural technologies and imparting many short days and long days vocational training programmes to rural youth and farmers. The farmers trained at KVK become more alert and fully aware citizen of the community. The KVK provides strong training support for training significant breakthrough in agricultural production. Keeping in view the above facts the study entitled as such given above. The study carried out in Kanpur Dehat and Lucknow districts in Central Uttar Pradesh. The data were collected through pretested interview schedule from randomly selected 160 trained and 160 untrained farmers. The data were analysed for logical conclusion. The trained respondents were having higher knowledge about improved rice cultivation technologies and high level of adoption in respect of HYV, seed rate, sowing time and sowing method, fertilizer application and plant protection measures of rice crop than untrained respondents. Investment pattern of trained respondents was more as compared to untrained respondents. The availability of input like seed, fertilizer, and plant protection measures enhanced the productivity and the employment in rice crop on farmers' field.

\section{Introduction}

The system of transfer of technology has played a crucial role in modernizing agriculture. Rice is one of the most important food crops of India. Major share of rice is cultivated during Kharif season. A small share of rice is grown in rabi /summer season with assured irrigation. In Indian, rice production largely depends on monsoon rains and only 60.10 per cent rice area has assured irrigation (Agricoop, 2017). In Uttar Pradesh, about 5.65 million hectare area with 12.95 million tonne production and $2295 \mathrm{~kg} / \mathrm{ha}$ productivity and irrigated area $86.70 \%$ are under rice cultivation. 
According to FAOSTAT (2016), the global rice industry produces 738.18 million tonnes of rice with $162.32 \mathrm{mha}$ area and $4548 \mathrm{~kg} \mathrm{ha}^{-1}$ yield in the year 2015. Asia region alone contributes over $90 \%$ with China and India contributing $29.3 \%$ and $17.9 \%$ shares of the total global output, respectively. Krishi Vigyan Kendra (KVK) is an innovative science based institution which under takes vocational training of farmers, farm women and rural youth, conducts on farm research for technology refinement and frontline demonstrations to promptly demonstrate the latest agricultural technologies to the farmers as well as the extension worker. The KVK function on the principles of collaborative participation of scientists, subject matter specialist, extension worker and farmers. The government of India has set a target of expanding the cultivation of rice with hybrid seed.

Current growth trends suggest that this target will not be met, despite the potential contribution of hybrid rice to lagging growth in national rice yields, overall rice production, land-use reallocation and food security. KVK is based on the recommendations of the education commission (1964-66) and interministerial committee (1973), ICAR (Indian Council of Agricultural Research) decided to establish KVKs in the country. A high level committee headed by Dr. Mohan Singh Mehta recommended the establishment of KVK to provide skill oriented vocational training support for farmers. Rice is grown under so diverse soil and climatic conditions that it is said that there is hardly any type of soil in which it can be grown including alkaline and acidic soils. Rice crop has also got wide physical adaptability.

\section{Materials and Methods}

The present study was conducted in Central plain zone of Uttar Pradesh to evaluate the knowledge and adoption on rice cultivation. The KVK provides strong training support for training to significant breakthrough in agricultural production. Keeping in view the above facts, the study entitled as such given above. The study carried out in Kanpur Dehat and Lucknow districts in Central Uttar Pradesh. The data were collected through pretested interview schedule from randomly selected 160 trained and 160 untrained farmers. The data were analysed for logical conclusion by using statistical tools like percentage, frequency, mean and t- test.

\section{Results and Discussion}

\section{Knowledge}

Knowledge is defined as the set of concepts, meanings, skills and routines development over time by individual and groups through processing of information. Once the knowledge is acquired, it also brings about changes in overt behaviour such as adoption. In the present study it was hypothesized that the extension activities of KVK such as on farm trial, farm and home visits, method and result demonstrations, trainings and field days would lead to an increase in knowledge of the respondents regarding the technological intervention.

The table 1 depicts that the mean score pertaining to knowledge of trained and untrained respondents regarding the technological intervention on rice were 50.90 and 43.19, respectively. The difference between mean scores was 7.71. The value of ' $\mathrm{t}$ ' ratio is 19.72 which is significant at 0.01 level of probability. This indicates that the respondents from trained category possessed significantly higher level of knowledge about improved rice cultivation technologies than the untrained respondents to improved rice cultivation technologies through various activities of KVKs. 
The respondents from trained category also possessed significantly higher level of knowledge about improved rice cultivation technologies. It may therefore be concluded that the various extension activities of KVKs helped in improving the knowledge level of the farmers regarding improved rice cultivation technologies.

It is evident from table 2 that majority $67.5 \%$ of the respondents from trained category had medium extent of knowledge; while $20 \%$ had high extent of knowledge, and $12.5 \%$ had low extent of knowledge. In untrained category the majority $76.875 \%$ respondents had medium extent of knowledge, while $18.125 \%$ were having low extent of knowledge and only $5 \%$ having high extent of knowledge.

The respondents from trained category also showed higher extent of knowledge This could be due to the exposure of the trained farmers to knowledge through on-farm trials conducted under KVKs. The untrained farmers lacked this opportunity and hence, they showed lower extent of knowledge of these technologies.

\section{Adoption}

The adoption is the function of an individual respondent. KVKs have made many efforts to provide trainings and required inputs to the respondents for more production, some of the respondents were doing well while others adoptions of the practices were on an average or at lower level. To record the level of adoption of each individual, we put them in various adoption levels.

It is evident from table 3 that out of 160 trained respondents, the $129(80.625 \%)$ were under high adoption category, 22(13.75\%) medium adoption category and 18(11.02\%) low adoption category. None was under no adoption category of adoption in case of high yielding varieties. For seed rate, sowing time and method of sowing 115(71.875\%) respondents were high adopter and remaining $47(29.375 \%)$ and $13(8.125 \%)$ were medium adopter and low adopter, respectively. With regard to fertilizer application, 110(68.75\%) were under high adopter category, $41(25.3625 \%)$ medium, $12(7.5 \%)$ low and $4(2.5 \%)$ were found non-adopter category. For plant protection measures, maximum $50(31.25 \%)$ were found under non adopters category 40(25\%) low, 45(28.125\%) medium and $32(20 \%)$ were found under high adopters category.

The overall scenario of this table indicates that except in plant protection, majority of the trained respondents were in high adoption category followed by medium adoption in respect of high yielding varieties, seed rate, sowing time and method of sowing, \& fertilizer application in rice crop. With regard to plant protection, the scenario with different as the majority of farmers were under nonadopter category followed by low, medium and high. This was due to high cost and unawareness about the plant protection chemical and its equipments. This is also due to non-seriousness of the cultivators.

It is clear from the above table 4 that out of 160 untrained respondents 102(63.75) were under high adoption category, 55(34.38\%) medium adoption category and 25(15.63\%) low adoption category. Only 5(3.15\%) were under no adoption category in HYV. For seed rate, sowing time, sowing method $81(50.63 \%)$ were of higher adoption category followed by medium adoption category, 28(17.5\%) low adoption category and remaining $6(3.75 \%)$ under no adoption category.

For fertilizer application 75(46.88\%) were under medium adopter category followed by 63(39.38\%) high adoption, 32(20\%) low adoption and 09(5.63\%) under no adoption 
category. In case of plant protection measures $90(56.25 \%)$ were found in no-adoption category followed by $33(20.63 \%)$ under low adoption category and $31(19.38 \%)$ under medium adoption category in plant protection measures. The overall picture of this table depicts that except in plant protection, majority of untrained respondents were in high adoption category followed by medium and low in the practices mentioned above. When we look for plant protection measures, the situation is just reverse because majority of the untrained respondents were under no adoption category and almost negligible number of respondents adoption same. This was due to higher cost involved in purchasing chemical and equipment and unawareness about the plant protection measures.

Table.1 Difference in knowledge about improved rice cultivation technologies between the trained and untrained respondents

\begin{tabular}{|c|l|c|c|c|}
\hline Sl.No. & Respondents & $\begin{array}{c}\text { Mean } \\
\text { (Score) }\end{array}$ & $\begin{array}{c}\text { Difference } \\
\text { In mean }\end{array}$ & $\begin{array}{c}\text { 't value of } \\
\text { mean }\end{array}$ \\
\hline $\mathbf{1 .}$ & Trained & 50.90 & 7.71 & $19.72 * *$ \\
\hline 2. & Untrained & 43.19 & & \\
\hline ** Significant at & 0.01 level of probability, $d f=318$ & & \\
\hline
\end{tabular}

Table.2 Distribution of the respondents according to their extent of knowledge about improved rice cultivation technologies $(\mathrm{N}=160)$

\begin{tabular}{|c|l|c|c|}
\hline Sl.No. & Categories & \multicolumn{2}{|c|}{ Frequency } \\
\cline { 3 - 4 } & & Trained & Untrained \\
\hline 1. & Low & $20(12.50)$ & $23(18.13)$ \\
\hline 2. & Medium & $108(67.50)$ & $123(76.88)$ \\
\hline 3. & High & $32(20.00)$ & $08(05.00)$ \\
\hline & Total & $160(100)$ & $160(100)$ \\
\hline
\end{tabular}

*Figures in parenthesis indicate percentages.

Mean $=73.06, \mathrm{SD}=1.44,($ Trained $)$, Mean $=61.71, \mathrm{SD}=7.35($ Untrained $)$

Table.3 Level of adoption of the trained respondents in relation to selected package of practices of rice

\begin{tabular}{|c|c|c|c|c|c|c|}
\hline $\begin{array}{c}\text { S. } \\
\text { No. }\end{array}$ & $\begin{array}{c}\text { Level of } \\
\text { adoption }\end{array}$ & Class range & HYV & $\begin{array}{c}\text { Seed rate, } \\
\text { Sowing time } \\
\text { and sowing } \\
\text { method }\end{array}$ & $\begin{array}{c}\text { Fertilizer } \\
\text { Appt. }\end{array}$ & $\begin{array}{c}\text { Plant } \\
\text { protection } \\
\text { measures }\end{array}$ \\
\hline 1. & $\begin{array}{c}\text { No } \\
\text { adoption }\end{array}$ & $00.00-00.00$ & - & - & 04 & 50 \\
\hline 2. & $\begin{array}{c}\text { Low } \\
\text { adoption }\end{array}$ & $0.01-30.00$ & 18 & 13 & $(2.50)$ & $(31.25)$ \\
\hline 3. & $\begin{array}{c}\text { Medium } \\
\text { adoption }\end{array}$ & $30.01-60.00$ & $(11.02)$ & $(8.125)$ & $(7.50)$ & $(25.00)$ \\
\hline 4. & $\begin{array}{c}\text { High } \\
\text { adoption }\end{array}$ & Above 60.00 & $(13.75)$ & $(29.38)$ & $(25.63)$ & $(28.13)$ \\
\hline
\end{tabular}

*Figures in parenthesis indicate percentages 
Table.4 Level of adoption of the untrained respondents relation to selected package of practices of rice

\begin{tabular}{|c|c|c|c|c|c|c|}
\hline SI. No. & $\begin{array}{l}\text { Level of } \\
\text { adoption }\end{array}$ & Class range & HYV & $\begin{array}{l}\text { Seed rate, } \\
\text { Sowing time and } \\
\text { sowing method }\end{array}$ & $\begin{array}{c}\text { Fertilizer } \\
\text { Application }\end{array}$ & $\begin{array}{c}\text { Plant } \\
\text { protection } \\
\text { measures }\end{array}$ \\
\hline 1. & $\begin{array}{c}\text { No } \\
\text { adoption }\end{array}$ & $00.00-0.00$ & $\begin{array}{c}05 \\
(03.15)\end{array}$ & $\begin{array}{c}06 \\
(03.75)\end{array}$ & $\begin{array}{c}09 \\
(05.63)\end{array}$ & $\begin{array}{c}90 \\
(56.25)\end{array}$ \\
\hline 2. & $\begin{array}{c}\text { Low } \\
\text { adoption }\end{array}$ & $0.01-30.00$ & $\begin{array}{c}25 \\
(15.63)\end{array}$ & $\begin{array}{c}28 \\
(17.50)\end{array}$ & $\begin{array}{c}32 \\
(20.00)\end{array}$ & $\begin{array}{c}33 \\
(20.63)\end{array}$ \\
\hline 3. & $\begin{array}{l}\text { Medium } \\
\text { adoption }\end{array}$ & $30.01-60.00$ & $\begin{array}{c}55 \\
(34.38)\end{array}$ & $\begin{array}{c}62 \\
(38.75)\end{array}$ & $\begin{array}{c}75 \\
(46.88)\end{array}$ & $\begin{array}{c}31 \\
(19.38)\end{array}$ \\
\hline 4. & $\begin{array}{c}\text { High } \\
\text { adoption }\end{array}$ & $>60.00$ & $\begin{array}{c}102 \\
(63.75)\end{array}$ & $\begin{array}{c}81 \\
(50.63)\end{array}$ & $\begin{array}{c}63 \\
(39.38)\end{array}$ & - \\
\hline
\end{tabular}

*Figures in parenthesis indicate percentages

The trained farmers have higher knowledge about improved rice cultivation technologies and high level of adoption of HYV, seed rate, sowing time and sowing method, fertilizer application and plant protection measures of rice crop than untrained respondents.

Knowledge and adoption about improved rice cultivation technologies by both trained and untrained respondents were found to be positively and significantly related to their education, occupation, size of family, size of land holding, annual income, material possession, social participation, management orientation and communication behavior, While age variable was positively correlated to knowledge and negatively correlated to adoption variable.

\section{References}

Agricoop (2017). Total rice area, production and productivity in India. Directorate of Economics and Statistics.

Babu, R. P and Sivanarayana, G. 2016. Constraints faced by the rice farmers in adoption of

recommended technologies in East Godavari district of Andhra Pradesh. Journal of Research ANGRAU. 44(1/2): 83-87.

Bhakthavatsalam, K. V. S.; Mundinamani, S.
M.; Rani, and D. J. Gayathri Mohan 2015. A comparative study on On-Farm Demonstration (OFD) to farmers fields for paddy cultivation in Dharwad district of Karnataka state. International Research Journal of Agricultural Economics and Statistics. 6(2): 342348.

Borthakur S; Mishra P; Talukdar R. K. and Bortamuly D. 2015. Scaling the Adoption of Recommended Rice Production Technologies by the Farmers in Assam State. Indian Res. J. Ext. Edu. 15(2): 30-35.

Chandawat, M. S; Bhimawat, B. B. S. and Jaitawat, G. S. 2004. Farmers opinion about KVK training. Indian Research Journal of Extension Education. 4(1\&2): 97-101.

FAO (2016). World agricultural statistics on rice production, area and productivity.

Gopal, P. V. S; Sreedevi, K. and Prasad, S. V. 2014. Constraints analysis of integrated pest management (IPM) in rice and the strategies to overcome the constraints. Current Biotica. 7(4): 306-313

Rayuda, B.T; Leena, S; Kumar, V; Krishna, Degde and Saritha .2003. Effectiveness of training knowledge level of farmers about Vanilla cultivation. Agricultural Extension Review. 15(5): 14-21. 


\section{How to cite this article:}

Sunil Kumar, H. C. Singh, Arun Kumar Rajbhar, Ramratan Singh and Ramvinay Pal. 2020. Analysis of Knowledge and Adoption of Rice Cultivators Trained by KVKs in Central Plain Zone of Uttar Pradesh, India. Int.J.Curr.Microbiol.App.Sci. 9(05): 1076-1081. doi: https://doi.org/10.20546/ijcmas.2020.905.118 